\title{
REVIEW
}

\section{Pathogenesis of human parvovirus B19 in rheumatic disease}

\author{
Jonathan R Kerr
}

Human parvovirus B19, discovered in $1975^{1}$ and first linked with human disease in $1981,{ }^{2}$ is a small single stranded DNA virus classified within the family Parvoviridae, and the genus Erythrovirus, having tropism primarily for erythroid precursors. B19 is the only parvovirus which has been clearly linked with disease in humans. It replicates only in human cells and is autonomous, not requiring the presence of a helper virus.

Acute B19 virus infection is classically associated with the childhood rash illness, erythema infectiosum (EI), arthralgia, fetal death, and transient aplastic crisis (TAC) in those with shortened red cell survival. However, it has been assumed that in those with a normal immune system, the virus has a relatively simple pathogenesis and that after the acute phase the virus is cleared by a specific humoral immune response. However, increasingly B19 virus and B19 infection have been reported in association with quite atypical and unpredictable findings based on previous assumptions. For example, persistence of the virus in various tissues after acute infection in apparently normal subjects and the association of B19 infection with various connective tissue and autoimmune diseases. This paper will therefore summarise present knowledge of the virus, its known and potential pathogenetic mechanisms, and its associations with human disease, with an emphasis on rheumatic disease.

\section{Virology}

The B19 genome consists of a single stranded linear molecule of 5596 nucleotides, which is composed of an internal coding sequence of 4830 nucleotides flanked by terminal repeat sequences of 383 nucleotides each. ${ }^{3}$ These terminal repeat sequences are imperfect palindromes and fold back on themselves to form hairpin loops. ${ }^{4}$ Viral replication is thus self primed by the $3^{\prime}$ terminus, ${ }^{5}$ and in minute virus of mice, a related parvovirus, has recently been shown to require the host cell transcriptional modulator, parvovirus initiation factor. ${ }^{6}$ This is a site-specific DNA-binding complex consisting of p96 and p79 subunits, which have $40 \%$ amino acid identity focused particularly within a 94 residue region containing the sequence KDWK, and may modulate transcription of many genes.
The P6 promoter at the far left side of the genome initiates transcription of all B19 proteins. ${ }^{7}$ The non-structural protein, NS1, is encoded by the left side of the genome (nucleotides 435-2448) and is approximately $77 \mathrm{kDa}{ }^{8}$ Parvovirus non-structural proteins are fairly homologous between species, consistent with their role in virus propagation, and B19 NS1 contains two phosphorylation sites, an amidation site and a nucleotide binding site. ${ }^{9} \mathrm{NS} 1$ is localised to the nucleus of infected cells, ${ }^{8}$ is found covalently bound to mature virions, ${ }^{10}$ and may nick its replicative DNA intermediates to facilitate viral packaging. ${ }^{5} \mathrm{NS} 1$ is cytotoxic to various host cells ${ }^{11}$ possibly owing to host DNA nickase activity, which is abrogated by mutations within the nucleoside triphosphate-binding domain. ${ }^{12}$ B19 NS1 has also been shown to upregulate human interleukin 6 (IL6) gene expression ${ }^{13}$ and to induce apoptosis in cells of the erythroid lineage. ${ }^{14}$

Structural proteins, VP1 and VP2, are encoded in the same open reading frame by nucleotides $2444-4786$ and $3125-4786$ with production of proteins of 84 and $58 \mathrm{kDa}$, respectively. ${ }^{75}$ VP1 and VP2 are identical except for an additional 227 amino acids at the amino terminus of VP1. Antibody to this unique VP1 region precipitates and neutralises the virus in erythroid culture and therefore this region is thought to protrude from the external virion surface into the milieu and may have a role in attachment. ${ }^{16}$ Parvovirus B19 particles are icosahedral (20-sided) and made up of 60 copies of the capsid proteins: $96 \%$ VP1 and 4\% $\mathrm{VP} 2,{ }^{17}$ a ratio resulting from the relative inefficiency of VP1 translation.

Study of the molecular epidemiology of B19 virus has shown variation of certain regions of the virus with time and geographical location and is increased in conditions where the virus persists and is allowed to undergo multiple rounds of replication, such as in fetal infection. ${ }^{18}$ Although considerable effort has focused on a possible relation between particular genetic subtypes of the virus and particular clinical manifestations, ${ }^{18}$ only in the case of B19 encephalopathy has there been a suggestion that this actually occurs. ${ }^{19}$

Culture of B19 virus is not possible using routine diagnostic methods but requires erythroid progenitor cell culture, and this is probably an important factor in the relatively 
late discovery of the virus and of its role in human disease. Erythroid progenitors from a number of different sources have been shown to support B19 replication, all of which require erythropoietin, presumably to maintain the cells in rapid division; these include human bone marrow, ${ }^{2021}$ fetal liver, ${ }^{22}{ }^{23}$ erythroid cells from a patient with erythroleukaemia, ${ }^{24}$ human umbilical cord blood, ${ }^{25} 26$ and peripheral blood. $^{27} 28$

The receptor for the $\mathrm{B} 19$ virus has been shown to be blood group $\mathrm{P}$ antigen or globoside (Gb4), ${ }^{29}{ }^{30}$ a glycosphingolipid. Glycosphingolipids are molecules present in the plasma membrane of all animal cells which modulate membrane receptors, act as microbial receptors, and are used to differentiate erythrocytes on the basis of $\mathrm{ABH}, \mathrm{I}$, and $\mathrm{P}$ blood group antigens. ${ }^{31} \mathrm{~Gb} 4$ is expressed on erythrocytes, platelets, granulocytes, lung, heart, synovium, liver, kidney, endothelium, and vascular smooth muscle, ${ }^{32}$ and may explain the tissue tropism observed clinically in B19 infection.

\section{Immunology of B19 infection}

Both virus capsid-specific IgM and IgG are produced after experimental ${ }^{33}$ and natural ${ }^{34}$ B19 infection. In TAC, IgM may be present at the time of reticulocyte nadir and during the subsequent 10 days. However, specific IgG does not appear until the time of recovery. IgM may persist in serum several months after exposure. ${ }^{35}$ IgA can also be detected and presumably plays a part in resistance to natural infection by the nasopharyngeal route. ${ }^{36}$ Antibodies to the NS1 protein are produced during infection in approximately $30 \%$ of subjects and have been associated with acute ${ }^{37}$ and chronic ${ }^{38}$ B19 arthritis, and persistent B19 infection. ${ }^{39}$ In normal subjects, resolution of B19 infection is associated with specific antibody production, which neutralises the virus in erythroid cell culture..$^{40}$ The humoral response is known to be crucial in disease resolution and was for many years thought to be the only important factor in protection. However, a cellular response to the capsid proteins was reported recently, ${ }^{41}$ the significance of which is unclear.

\section{Pathogenesis of disease associated with B19 infection}

The pathogenesis of B19 virus infection is complex, particularly when the less common clinical manifestations/associations are included. Although this review discusses each potential pathogenetic mechanism separately, it should be remembered that these do not occur separately in vivo, and during the pathogenesis of a single B19 infection a combination of these mechanisms may come into play. However, clearly, the importance of each will vary depending on the particular virus/host interaction (table 1).

It is believed that the virus usually gains access to the human host by aerosol droplet transmission and that infection is usually by inhalation of these infected droplets into the respiratory tract. ${ }^{33}$ However, B19 may also be transmitted parenterally by infected blood and blood products. ${ }^{42} 43$

\section{LOCAL VIRAL REPLICATION}

During the incubation period, the virus seems to multiply in the throat, leading to viraemia on day $6,{ }^{33}$ with infection of erythroblasts in the bone marrow, ${ }^{44}$ after attachment to these cells through the $\mathrm{Gb} 4$ receptor. ${ }^{29}{ }^{30} \mathrm{~Gb} 4$ is expressed on erythrocytes, platelets, granulocytes, lung, heart, synovium, liver, kidney, endothelium, and vascular smooth muscle, ${ }^{32}$ and may explain the tissue tropism observed clinically in B19 infection. Local viral replication may therefore represent a primary pathogenetic mechanism

Table 1 Pathogenetic mechanisms known or proposed to account for various clinical syndromes associated with parvovirus B19 infection

\begin{tabular}{|c|c|c|c|c|c|c|c|c|}
\hline & $\begin{array}{l}\text { Local viral } \\
\text { replicationt }\end{array}$ & $\begin{array}{l}\text { NS1 } \\
\text { cytotoxicity } \neq\end{array}$ & $\begin{array}{l}\text { Immune complex } \\
\text { deposition } \uparrow\end{array}$ & $\begin{array}{l}\text { Erythroblast } \\
\text { apoptosis } \star \star\end{array}$ & $\begin{array}{l}\text { Autoantibody } \\
\text { productiontt }\end{array}$ & $\begin{array}{l}\text { Cytokine } \\
\text { upregulationf } \neq\end{array}$ & Persistence $\mid \uparrow$ & References \\
\hline \multicolumn{9}{|c|}{ Clinical syndromes commonly associated with B19 infection* } \\
\hline TAC & + & & & + & & & & $14,40,46$ \\
\hline EI & + & + & + & + & & & & $14,33,44,45$ \\
\hline Hydrops fetalis & + & & & + & & & & 48,55 \\
\hline Arthralgia/arthritis & & ? & + & & & ? & $?$ & $13,33,46,52,71$ \\
\hline Chronic PRCA & + & & & + & & & + & $14,47,81$ \\
\hline \multicolumn{9}{|c|}{ Clinical syndromes less commonly associated with B19 infection ${ }^{\star}$} \\
\hline Skin eruptions & + & & + & & ? & $?$ & + & $13,33,45,46,62,85$ \\
\hline Aplastic anaemia/cytopenias & + & + & & + & & + & + & $13,14,72,155,158$ \\
\hline Hepatitis & + & & & & & & & 79 \\
\hline Encephalopathy/meningitis & + & & & & & & & $169,173-176$ \\
\hline Peripheral neuropathy & & & + & & & & & 53,54 \\
\hline CFS & & & & & & $?$ & + & $13,59,86,184-187$ \\
\hline RA & + & & & & + & + & + & $13,49,62,82$ \\
\hline SLE & + & & & & + & ? & + & $61,111,230-238$ \\
\hline Vasculitis & + & & ? & & ? & ? & + & $220-227$ \\
\hline
\end{tabular}

${ }^{\star} \mathrm{TAC}=$ transient aplastic crisis $; \mathrm{EI}=$ erythema infectiosum $;$ PRCA $=$ pure red cell aplasia $; \mathrm{CFS}=$ chronic fatigue syndrome RA $=$ rheumatoid arthritis SLE $=$ systemic lupus erythematosus.

†Local B19 replication occurs primarily in the erythroblasts, but also occurs in macrophages, myeloid cells, lymphocytes, hepatocytes, and dendritic epidermal and endothelial cells.

$\ddagger \mathrm{B} 19$ NS1 cytotoxicity is thought to account for haematological abnormalities in EI and cytopenias and possibly for arthralgia/arthritis

IImmune complex deposition is thought to account for the rash of EI, arthralgia, peripheral neuropathy and may contribute to other B19 associated skin rashes and vasculitis.

$\star \star$ Erythroblast apoptosis, mediated by the NS1 protein, occurs in TAC, EI, and hydrops fetalis and probably also in PRCA and aplastic anaemia/cytopenias.

+†Anti-B19 VP1 IgG cross reacts with collagen II and keratin, which may be significant in the pathogenesis of arthritis/RA and skin pathology, respectively. Antiphospholipid antibodies occur after B19 infection and may be important in the pathogenesis of symptoms which mimic SLE.

执Upregulation of human IL6, mediated by the NS1 protein, may be important in aplastic anaemia/cytopenias and B19 associated RA; possibly also in B19 arthritis, B19 associated skin rashes, and B19 associated CFS.

ПथPersistence of B19 is important in PRCA, may be important in B19 associated skin rashes, arthritis, CFS, RA, SLE, and vasculitis. 
in EI, TAC, chronic bone marrow failure, congenital red cell aplasia, vasculitis, and hepatitis. In EI, B19 replication occurs in erythroblasts with temporary cessation of reticulocyte production and reduction of the haemoglobin level by about $10 \mathrm{~g} / \mathrm{l}^{3344}$ This is a temporary phenomenon and usually subclinical owing to the normal red cell survival and the rapid development of a neutralising humoral immune response. ${ }^{334}$ Local viral replication has also been shown in epidermal cells in the stratum basale in EI. ${ }^{45}$ In TAC, B19 replication occurs in the erythroblasts with haemolysis and anaemia owing to the inability of red cell development to keep pace with haemolysis. ${ }^{46}$ However, if survival of the acute phase is assumed, virus is cleared by neutralising antibodies, and the erythroid progenitors are regenerated from earlier haemopoietic cells. Chronic pure red cell aplasia (PRCA) occurs in immunocompromised subjects who do not mount an adequate immune response with ongoing replication of the virus in erythroblasts. ${ }^{47}$ In fetal infection, B19 replication is thought to be important and may occur in several organs, including the bone marrow, liver, and heart. ${ }^{48} \mathrm{~B} 19$ protein expression has also been shown in macrophages, follicular dendritic cells, and $\mathrm{T}$ and $\mathrm{B}$ lymphocytes from patients with RA. ${ }^{49}$ Although human synoviocytes do express $\mathrm{Gb} 4{ }^{32}$ they seem to be non-permissive to B19 virus. ${ }^{50}$

\section{NS1 CYTOTOXICITY}

Cytotoxicity due to parvovirus B19 is directly related to the cytotoxicity of the NS1 protein, ${ }^{11}$ and NS1 cytotoxicity is thought to account for thrombocytopenia and leucopenia occurring during B19 infection. ${ }^{44}{ }^{51}$ NS1 cytotoxicity has also been suggested as a possible mechanism in the arthralgia/arthritis of B19 infection.

IMMUNE COMPLEX DEPOSITION

Immune complex deposition is thought to occur in EI and in the acute polyarthropathy of B19 infection. In volunteer studies, appearance of rash and joint symptoms coincided with disappearance of viraemia and appearance of specific IgG. ${ }^{33}$ In addition, rash and joint symptoms are known to occur in chronically infected subjects after treatment with immunoglobulin. ${ }^{52}$ The coincidence of peripheral nerve abnormalities with the appearance of anti-B19 IgG is also consistent with an immune mediated pathogenesis. ${ }^{53} 54$

ERYTHROBLAST APOPTOSIS

B19 infection of erythroid lineage cells is characterised by a gradual cytocidal effect mediated by NS1 protein, ${ }^{20}$ and by features of apoptosis. ${ }^{55}$ It has recently been shown that NS1 is responsible for apoptosis of erythroid cells, an activity which was abolished by nucleotide mutation within the nucleoside triphosphate binding site of NS1. ${ }^{14} \mathrm{NS} 1$ mediates apoptosis by a pathway that involves caspases 3,6 , and 8 and seems to be mediated by an increase in sensitivity to apoptosis induced by tumour necrosis factor $\alpha(\mathrm{TNF} \alpha){ }^{56}$
PRODUCTION OF AUTOANTIBODIES

Some clinical features of B19 infection are similar to those of autoimmune connective tissue diseases. However, the relation between B19 infection and these conditions is unclear. B19 infection has been associated with development of rheumatoid factor, ${ }^{57-59}$ antinuclear antibody, antimitochondrial antibody, smooth muscle antibody, and gastric parietal cell antibody. ${ }^{60}$ Antiphospholipid antibodies produced during acute B19 infection seem to have the same specificity as those produced in systemic lupus erythematosus (SLE). ${ }^{61}$ Lunardi and colleagues have shown that in patients with skin rashes, rheumatoid arthritis (RA), and chronic B19 arthritis, anti-VP1 IgG, which has been affinity-purified using a synthetic B19 VP1 peptide, reacted specifically with human keratin, collagen type II, single stranded DNA, and cardiolipin. ${ }^{62}$ The main reactivity was against keratin and collagen type II, and there was a correlation between the clinical features and the main autoantigen specificity; immunoglobulin from patients with arthritis reacted preferentially with collagen II, whereas immunoglobulin eluted from patients with skin rashes reacted preferentially with keratin..$^{62}$ As type II collagen is a target antigen of autoantibodies and clonally expanded $T$ cells in the RA synovium, ${ }^{63}$ this finding may have considerable significance in the proposed link between B19 infection and RA.

CYTOKINE UPREGULATION

Using human haemopoietic cell lines, K562, Raji, and THP-1, stably transfected with DNA encoding the NS1 protein and expressing NS1 on induction, it was shown that upon induction of NS1 expression the cells secreted IL6. ${ }^{13}$ Transient induction of IL6 was also shown in human endothelial cells. This effect of NS1 was mediated by the NF- $\kappa \mathrm{B}$ site in the IL6 promoter region, implying that NS1 functions as a trans-acting transcriptional activator on the IL6 promoter. This finding supports the possible association between B19 infection and polyclonal B cell activation in RA and suggests that NS1 mediated induction of host cell genes may have a role in clinical manifestations of B19 infection. ${ }^{13}$

Human T cell leukaemia type 1 (HTLV-1) tax protein is necessary for viral propagation and activates IL6 production, probably through the NF- $\mathrm{BB}$ binding site in the IL6 promoter. ${ }^{64}{ }^{65}$ Human immunodeficiency virus type 1 (HIV-1) tat protein also trans-activates IL6 production. ${ }^{66}$ These two proteins resemble B19 NS1 in that they play a part in replication and activation of viral and host genes. HTLV-1 is known to cause a chronic inflammatory arthropathy in humans, ${ }^{67}$ and HTLV-1 transgenic mice develop an arthropathy resembling RA. ${ }^{68}{ }^{69} \mathrm{HTLV}-1$ tax protein leads to overgrowth of human synovial cells. ${ }^{70}$

There is scanty documentation of serum cytokine levels occurring in B19 infection. One report documents a 63 year old woman with acute B19 infection and polyarthritis with transcript mRNA concentrations of IL $1 \beta$, IL6, and interferon $\gamma$ which were increased by 
factors of 32, 8, and 16, respectively. This suggests that acute B19 infection is associated with widespread and systemic activation of monocytes, $\mathrm{T}$ cells, and natural killer cells, which may have a role in disease manifestations. ${ }^{71}$ Raised serum $\mathrm{TNF} \alpha$ was reported in a case of B19 related pancytopenia and haemophagocytosis with hereditary spherocytosis. ${ }^{72}$ However, the normal cytokine response to parvovirus $\mathrm{B} 19$ is unknown, and so the clinical significance of the ability of B19 NS1 to upregulate IL6 remains unclear.

\section{ALTERED IMMUNE FUNCTION}

$\mathrm{P}$ antigen occurs on many human cells including lymphocytes, ${ }^{32}$ and B19 virus has been shown to infect and persist in both $\mathrm{T}$ and $\mathrm{B}$ lymphocytes. ${ }^{49}$ This together with the potential B19 NS1 mediated upregulation of IL $6^{13}$ may alter host cellular immunity. NS1 upregulation of IL6 is mediated by the NF- $\mathrm{KB}$ site, a mechanism thought to be similar to the upregulation of IL6 by HTLV-1 tax protein ${ }^{64}{ }^{65}$ and HIV-1 tat protein. ${ }^{66}$ Both HIV-1 and HTLV-1 persist in lymphocytes by integration and are associated with immunosuppression. Aleutian mink disease parvovirus causes persistent infection in mink associated with polyclonal hypergammaglobulinaemia and immune-complex mediated vasculitis and glomerulonephritis. ${ }^{73-76}$ Aleutian mink disease parvovirus replication occurs at a very slow rate in lymphoid tissue and involves macrophages and follicular dendritic cells, and immunosuppression is thought to play a part. ${ }^{77} 78$

PERSISTENCE OF PARVOVIRUS B19 IN THE HUMAN BODY

Infectious B19 virus has been shown at various sites in the human body, including throat, ${ }^{33}$ bone marrow, ${ }^{33}{ }^{44}$ liver, ${ }^{79}$ and synovium. ${ }^{49}$ Cell types infected by B19 virus include erythroblasts, megakaryoblasts, granulocytes, macrophages, follicular dendritic cells, $\mathrm{T}$ and $\mathrm{B}$ lymphocytes, hepatocytes, and endothelial cells. ${ }^{49}{ }^{49}{ }^{70} \mathrm{~B} 19$ virus DNA has been shown to persist in various sites of the human body, including bone marrow, ${ }^{81}$ synovium, ${ }^{80} 8283$ testis, ${ }^{84}$ and skin, ${ }^{85}$ but the mechanism which facilitates this persistence is unclear. In one study B19 viraemia was shown to occur in seven of 53 subjects, 3-5 years after acute B19 infection. ${ }^{86}$

Adeno associated virus (AAV) is a human dependovirus of the family Parvoviridae which is not associated with any human disease and is able to stably integrate its genome into chromosome 19 in a site-specific manner. ${ }^{87}$ The terminal sequences of AAV and B19 are almost identical and are palindromic repeat sequences. ${ }^{4}$ In $\mathrm{AAV}$ the terminal repeat sequences are important for viral replication, packaging of DNA, and integration. The fact that in AAV and B19 these repeats are so similar suggests biological similarities and, in particular, that B19 might integrate into the human chromosome and establish latency. However, although this has been sought in human tissues, so far there is no direct published evidence to support this speculation.

\section{Natural history of B19 infection}

Experimental infection in human volunteers elucidated the natural history of B19 infection. ${ }^{33}{ }^{44}$ After an incubation period of one week following intranasal inoculation, viraemia occurred on day 6, accompanied by a mild illness with pyrexia, myalgia, pruritis, and excretion of virus from the respiratory tract. During viraemia, peripheral blood reticulocytes were undetectable and the haemoglobin was slightly reduced; clinically non-significant lymphopenia, neutropenia, and thrombocytopenia also occurred. Haematological abnormalities rapidly returned to normal. During the second week the titre of viraemia fell and $\operatorname{IgM}$ appeared; specific IgM has been shown to persist for two to three months. During the third week, IgG appeared coincident with a fine, maculopapular skin rash and arthralgia. In this study the prior presence of IgG was protective.

Patients who presented with acute B19 infection have been followed up to determine the incidence of various symptoms during convalescence. However, these studies have provided conflicting data. For example, Kerr and colleagues followed up 53 such subjects, of whom at acute infection, $79 \%$ had arthritis and $62 \%$ had rash; 9 of $53(17 \%)$ complained of chronic joint pain which had persisted during the entire follow up period (mean 4.75 years). ${ }^{59}$ Conversely, Speyer and colleagues followed up 54 subjects who had acute B19 infection, of whom at acute infection, $61 \%$ had arthritis and $72 \%$ had rash; however, none of these patients had chronic arthritis after a mean follow up of five years. ${ }^{88}$

\section{Clinical syndromes commonly associated with B19 infection}

TRANSIENT APLASTIC CRISIS (TAC)

The first clinical syndrome to be associated with B19 infection was TAC in patients with sickle cell disease. ${ }^{2}$ TAC was well recognised previously as an acute drop in haemoglobin associated with cessation of reticulocyte production against a background of chronic haemolytic anaemia. B19 infection is now known to cause TAC in association with shortened red cell survival owing to a variety of conditions, which include sickle cell anaemia, ${ }^{289} \alpha$ and $\beta$ thalassaemia, ${ }^{90} 91$ autoimmune haemolytic anaemia, ${ }^{3492}$ glucose-6-phosphate dehydrogenase deficiency, ${ }^{93}$ hereditary spherocytosis, ${ }^{94} 95$ hereditary stomatocytosis, ${ }^{96}$ iron deficiency anaemia, ${ }^{97}$ pyruvate kinase deficiency, ${ }^{98}$ sideroblastic anaemia, ${ }^{99}$ hereditary erythrocytic multinuclearity associated with a positive acidified (HAMS) test (HEMPAS), ${ }^{100}$ and pyrimidine 5 '-nucleotidase deficiency. ${ }^{101}$ Patients are highly infectious at the time of presentation of TAC and should be isolated and barrier nursed.

\section{ERYTHEMA INFECTIOSUM (EI)}

EI or fifth disease is the major manifestation of B19 infection and was well studied before the discovery of B19 virus. ${ }^{102-104}$ It is characterised by a non-specific prodromal illness that often goes unnoticed but may cause fever, coryza, headache, nausea, and diarrhoea. In classic 
cases the exanthem occurs in three stages. The first begins 18 days after acquisition of infection and is characterised by a "slapped cheek" eruption with relative circumoral pallor. The second stage occurs one to four days later with an erythematous maculopapular rash on the trunk and limbs, which may spread to affect large areas. Towards the end of this stage there is central clearing of the rash to give the characteristic lacy or reticular pattern. The third stage is highly variable in duration, lasting one to three or more weeks, and is characterised by marked changes in rash intensity related to environmental factors such as sunlight and temperature. ${ }^{46}$ As the rash occurs at the same time as appearance of specific IgG, it is assumed that the rash is the result of immune complex deposition and therefore patients are not infectious at the time of presentation of EI.

ARTHRALGIA/ARTHRITIS

Joint symptoms associated with B19 infection occur in approximately $8 \%$ of children and up to $80 \%$ of adults, most of these being women. ${ }^{103}{ }^{105-107}$ Affected joints are painful, swollen, and stiff. B19 arthralgia may affect any joint but usually occurs symmetrically in the wrist, hand, knee, and ankle. ${ }^{57} 105108$ Joint symptoms last for one to three weeks, although in $20 \%$ or more of affected women, arthropathy may persist for months to years. In those with prolonged symptoms there is no corresponding increase in the amount or duration of anti-B19 IgM. Arthralgia may also occur without the rash.

B19 arthritis often meets clinical diagnostic criteria for RA, ${ }^{108-110}$ can be erosive,,$^{58111-113}$ is not infrequently followed by development of rheumatoid factor, ${ }^{58} 59109$ and B19 DNA may be detected in synovial fluid, ${ }^{114}$ cells, ${ }^{115}$ and tissue $^{80}$ of affected joints. The RA associated HLA-DR4 antigen was present in 12 of 18 patients with B19 associated arthropathy in one study, ${ }^{116}$ and was associated with prolonged arthritis after B19 infection (more than one year) in another. ${ }^{117}$ HLA-B27, associated with ankylosing spondylitis, has been associated with chronicity of arthritis in three of three B19 infected subjects, compared with none of five subjects with other HLA types. ${ }^{118}$ However, other studies found no association between the development of B19 arthritis and HLA type. ${ }^{119}$

NON-IMMUNE HYDROPS FETALIS

In 1984 B19 infection during pregnancy which led to hydrops fetalis and fetal death was reported, ${ }^{120}$ and this was followed by many more reports. ${ }^{48}$ Normal fetal erythrocyte survival may be as low as 45 days and during the second trimester fetal red cell mass increases 30 -fold. ${ }^{121}$ Therefore, the fetus is extremely dependent on this increased rate of erythropoiesis. During fetal B19 infection, erythropoiesis is arrested and the affected fetus develops an aplastic crisis with high output cardiac failure and oedema. ${ }^{48}$ Viral myocarditis has also been reported. ${ }^{122}{ }^{123} \mathrm{~B} 19$ infection during pregnancy has been estimated to result in fetal infection in $30 \% .{ }^{124}$ However, the incidence of fetal death after B19 infection in pregnancy is probably of the order of $1.66 \%{ }^{125}-9.2 \%,{ }^{124}$ and the likeli- hood of a favourable outcome is therefore high. ${ }^{5124125}$ Congenital syndromes have been reported but are extremely rare; fetal B19 infection has been associated with malformations in two cases in which the pregnancy was terminated, ${ }^{126}{ }^{127}$ and the rare congenital red cell aplasia (Diamond-Blackfan anaemia). ${ }^{128}$

CHRONIC PURE RED CELL APLASIA (PRCA)

Patients with immunosuppression may not be able to control B19 viraemia resulting in persistently low titre B19 viraemia accompanied by PRCA. Syndromes predisposing to persistent B19 viraemia and PRCA include acquired immunodeficiency syndrome (AIDS), ${ }^{47}$ chemotherapy for acute lymphoblastic leukaemia, ${ }^{129}$ acute lymphocytic leukaemia, ${ }^{130}$ chronic myelomonocytic leukaemia, ${ }^{131}$ patients with cancer receiving chemotherapy treatment, ${ }^{132}$ transplantation of bone marrow, ${ }^{133}$ heart, ${ }^{134}$ and liver, ${ }^{135}$ steroid treatment of SLE, ${ }^{136}$ and congenital immunodeficiency, including Nezelof's syndrome, ${ }^{137}$ common variable immunodeficiency, ${ }^{138}$ and severe combined immunodeficiency. ${ }^{139}$ Persistent B19 infection is thought to result from a defect in the humoral response to the B19 structural proteins which does not neutralise the virus. ${ }^{140}$ Normal human immunoglobulin, which contains neutralising antibodies to the virus, is the only specific treatment.

\section{Clinical syndromes less commonly} associated with B19 infection

CUTANEOUS MANIFESTATIONS

Various cutaneous eruptions have been reported in addition to the classic picture of EI. Petechial and purpuric rashes, including Henoch-Schönlein purpura, have been reported most commonly, both with and without thrombocytopenia. ${ }^{141-144}$ Papular eruptions have also been described, including "gloves and socks" syndrome ${ }^{145} 146$ and Gianotti-Crosti syndrome. ${ }^{147} 148$ Other cutaneous manifestations, reported rarely, include desquamation, ${ }^{149}$ vesiculobullous and vesiculopustular eruptions, including erythema multiforme, ${ }^{150-152}$ livedo reticularis, ${ }^{153}$ and erythema nodosum. ${ }^{154}$

HAEMATOLOGICAL DISORDERS

B19 infection has been associated with aplastic anaemia, ${ }^{155} 156$ neutropenia, ${ }^{157}{ }^{158}$ PRCA, ${ }^{47}{ }^{129-139}$ haemophagocytic syndrome, ${ }^{159}$ which may be fatal, ${ }^{160}$ hypersplenism, ${ }^{161}$ idiopathic thrombocytopenic purpura, ${ }^{162}$ lymphadenopathy, ${ }^{163}$ transient erythroblastopenia of childhood, ${ }^{164}$ and chronic necrotising lymphadenitis (Kikuchi's disease) in association with SLE. ${ }^{165}$

\section{HEPATOBILIARY DISEASE}

B19 infection has been associated with mildly raised liver enzymes in adults and neonates, ${ }^{166} 167$ non-A, non-B, non-C hepatitis fulminant liver failure with or without aplastic anaemia requiring liver transplantation, ${ }^{79} 168$ and acute childhood hepatitis. ${ }^{169} 170$

\section{NEUROLOGICAL DISEASE}

Central nervous system syndromes associated with B19 infection include encephalopathy, ${ }^{19} 169{ }^{171-173}$ meningitis, ${ }^{102} 174175$ new onset 
of seizures, ${ }^{172}{ }^{176}$ stroke, ${ }^{177}$ transverse myelitis, ${ }^{178}$ Guillain-Barré syndrome, ${ }^{179}$ and acute cerebellar ataxia, ${ }^{180}$ and B19 DNA has been detected in cerebrospinal fluid in several serologically confirmed cases of acute B19 related encephalopathy and meningitis. ${ }^{169}$ 173-176 Peripheral nerve abnormalities associated with B19 infection include brachial plexus neuropathy, ${ }^{53}{ }^{54}$ carpal tunnel syndrome, ${ }^{181}$ paraesthesias, ${ }^{182}$ myasthenia-like weakness, ${ }^{153}$ and paralysis of the ulnar nerve. ${ }^{183}$

\section{RHEUMATIC DISEASES}

Chronic fatigue syndrome/fibromyalgia

Chronic fatigue syndrome (CFS) is characterised by debilitating fatigue accompanied by a variety of symptoms, including neurocognitive symptoms, myalgia, and arthralgia lasting at least six months. ${ }^{184}$ It is thought that the pathogenesis of CFS may involve an infectious trigger, leading to chronic activation of the immune system with ongoing dysregulated cytokine production, and studies have shown increased levels of IL6, both in the circulation and released by stimulated lymphocytes. ${ }^{185} 186$ There are several examples of CFS after acute B19 infection; some of which have been published $^{59187}$ and some not. One of these cases responded to treatment with normal human immunoglobulin. ${ }^{187}$ Ilaria and colleagues examined seven patients with CFS; serum and bone marrow were negative for B19 DNA, all patients were anti-B19 IgG negative, and one patient with CFS and thrombocytopenia was anti-B19 IgM positive. ${ }^{188}$ The authors concluded that B19 is unlikely to play a significant part in the CFS. However, there are two problems with this conclusion. It is thought that CFS may be triggered by various infectious agents/insults which, in the author's opinion, include B19 virus, and as this study included only seven patients with CFS at one time point, the number of patients examined is too small to enable meaningful conclusions to be drawn.

In view of the definition ${ }^{184}$ and proposed pathogenesis $^{185} 186$ of CFS, attempts to determine the role of B19 in CFS by examining patients with CFS at one time point are clearly disadvantaged, unless they examine a significant number of patients, and even then the virus may no longer be present or be present in an atypical form. An alternative strategy which would seem to be more appropriate is to follow up a cohort of patients with acute B19 infection to determine the incidence of CFS after B19 infection, and then to examine further those particular patients in whom one is sure that the CFS was triggered by B19 infection. One such study followed up 53 patients with acute B19 infection; after 4.75 years follow up, two of these had CFS and one had B19 virus detected in the blood. ${ }^{59}$ In conclusion, therefore, the role of B19 in CFS warrants further investigation.

Fibromyalgia is a chronic disorder of unknown cause characterised by generalised musculoskeletal pain and tenderness in the absence of synovitis or myositis, ${ }^{189}$ and there is considerable overlap between the features of fibromyalgia and those of the CFS. Three cases of fibromyalgia have been reported after docu- mented B19 infection, ${ }^{190}$ but, as for the CFS, B19 virus is probably only one of a number of triggers. ${ }^{191}$

\section{Rheumatoid arthritis}

$\mathrm{RA}$ is a chronic systemic inflammatory disease of unknown cause and characterised by symmetrical, destructive polyarthritis. As mentioned previously, the possible role of B19 in RA was suggested by the fact that B19 arthritis often met clinical diagnostic criteria for RA, ${ }^{108-110}$ could be erosive, ${ }^{58} 111-113$ was not infrequently followed by development of rheumatoid factor, , $^{59} 109$ and B19 DNA could be detected in synovial fluid, ${ }^{114}$ cells, ${ }^{115}$ and tissue ${ }^{80}$ of affected joints. The RA associated HLADR4 antigen was present in 12 of 18 patients with B19 associated arthropathy in one study, ${ }^{116}$ and was associated with prolonged arthritis after B19 infection (more than one year) in another. ${ }^{117}$

Various groups have examined the incidence of anti-B19 IgM in patients at onset of RA and generally found this to be in the range of only 2-6\%. ${ }^{58110}{ }^{192}$ However, Murai and colleagues reported viral DNA and anti-B19 IgM in 12 of 67 patients $(18 \%)$ with acute onset inflammatory arthritis. ${ }^{193}$ Findings on the incidence of anti-B19 IgG in patients with RA are conflicting, but the $\operatorname{IgG}$ seroprevalence is generally what would be expected for the particular age group and is considerably less than $100 \%,{ }^{58} 8082194-196$ indicating that many patients with RA are unlikely to have been previously infected with the virus. Studies looking for B19 DNA in various tissues have again yielded conflicting results. Generally, B19 DNA has not been found in serum ${ }^{82} 8110$ and synovial fluid $^{110197}$ of patients with RA. However, in the synovium Saal and colleagues detected B19 DNA in synovial biopsy specimens from $75 \%$ (15 of 20) of patients with RA compared with $17 \%$ (4 of 24) of patients with other arthritides; five patients with RA with B19 DNA in synovium were serum anti-B19 IgG negative. ${ }^{80}$ Kerr and colleagues detected B19 DNA in synovium from $38 \%$ (10 of 26) of patients with chronic RA compared with 35\% (9 of 26) of patients with osteoarthritis (OA); all patients with B19 DNA in synovium were serum anti-B19 IgG positive. ${ }^{82}$

Takahashi and colleagues detected B19 DNA in the synovium in 30 of 39 patients with $\mathrm{RA}$, in four of 26 patients with OA, and in five of 31 traumatic joints; B19 VP1 was expressed in all 27 patients with RA with active synovial lesions, but not in patients with $\mathrm{OA}$ and controls. ${ }^{49}$ Infectious virus was shown in $\mathrm{T}$ and B lymphocytes, macrophages, and follicular dendritic cells, and B19 infection of various cell types was associated with increased IL6 and TNF $\alpha$ production. ${ }^{49}$ Another human parvovirus, RA-1, was isolated from cultured synovial tissue from a patient with $\mathrm{RA},{ }^{198}$ the sequence of which shows homology to bovine parvovirus. ${ }^{199}$ RA-1 was lethal for mice on intracerebral inoculation, and antisera to RA-1 reacted with cultured synovium from other RA cases. However, no further work has been published on this virus. 
In three cases in which RA developed after acute B19 infection, at two to four months after onset, rheumatoid factor was detected in serum and two to three years later rheumatoid nodules and erosive joint changes occurred ${ }^{193}$; six years later B19 DNA and capsid antigen were detected in bone marrow, tonsil tissue, and synovium, but not in blood. It was also shown that B19 DNA and VP1 protein occurred in erythroblasts, lymphocytes, stroma cells, and synovial tissue cells. But these additional cells were not positive in other B19 associated diseases. ${ }^{193}$

A distinctive characteristic of RA is the degradation of cartilage by activated synovial fibroblasts, and it has been shown that incubation of synovial fibroblast cell lines with B19-containing sera increases their invasiveness for a cartilage membrane. ${ }^{200}$

It seems that RA is a relatively new disease in Europe as judged from writings, paintings, ${ }^{201}$ and the study of skeletons, ${ }^{202}{ }^{203}$ and it may have appeared after the return of the explorers from the new world towards the end of the 15 th century. This differs from the situation in North America, where RA has existed for many thousands of years. ${ }^{204}$ The first description of a disease compatible with EI did not occur until $1797 .{ }^{205} 206$ Therefore, B19 was probably a new virus to Europe at this time and this is consistent with a role for the virus in the pathogenesis of RA. Detection of B19 DNA in the ancient new world and not in the old world would provide evidence that $\mathrm{B} 19$ virus is new to Europe. ${ }^{204}$

Clearly, there are suggestions of the involvement of B19 in the pathogenesis of RA-for example, the fact that chronic B19 arthritis may be indistinguishable from classic RA, HLA associations, rheumatoid factor production, raised $\operatorname{IgM}$ antibodies in some studies, the finding in one study of B19 DNA and protein expression in $100 \%$ of patients with active synovial lesions, ${ }^{49}$ demonstration of infectious virus in macrophages and $\mathrm{T}$ and $\mathrm{B}$ lymphocytes in patients with RA, ${ }^{49}$ development of classic RA after acute B19 infection, ${ }^{193}$ the increased invasiveness of synovial fibroblasts incubated with B19-containing serum, ${ }^{200}$ cross reactivity of anti-B19 VP1 IgG with human collagen II, ${ }^{62}$ and epidemiological data suggesting that both B19 and RA are new world diseases. ${ }^{204}$ In addition, IL6 synthesis is known to be upregulated at the transcriptional level in rheumatoid synoviocytes, ${ }^{207}$ and this is consistent with a B19 NS1 mediated effect. ${ }^{14}$ However, if B19 does cause RA, why then is the literature in this area discrepant? The answer may relate to several factors: heterogeneity in the disease entity of RA, differences in the timing of sampling with respect to the onset of arthritis between different studies, possible differences in host response to B19 virus with ethnic origin, an as yet unrecognised reservoir for the virus, unknown biological effects of the virus or its proteins, the possibility of additional infectious trigger/s in addition to B19 infection, and the lack of prospective studies in this area.
Fuvenile idiopathic arthritis

Juvenile idiopathic arthritis (JIA) (Still's disease) is a heterogeneous group of chronic rheumatic diseases affecting children younger than 16 years of age. The clinical presentations of JIA and acute B19 infection overlap considerably, and onset of JIA has been recorded in patients with acute B19 infection. ${ }^{208-212}$ Six of 22 children with B19 associated arthropathy fulfilled diagnostic criteria for both pauciarticular and polyarticular JIA. ${ }^{209}$ In another study five of 11 patients with chronic polyarticular JIA were positive for serum anti-B19 IgG compared with five of 60 age matched controls. ${ }^{194}$ In a recent study from India, 28 of 69 patients with JIA were anti-B19 IgM positive compared with none of 26 patients and one of 12 healthy controls. ${ }^{213}$ Remission of JIA has also been reported with acute B19 infection. ${ }^{214}$ B19 infection has been associated with the development of a case of Still's disease, thrombocytopenia, and acute hepatitis $^{215}$ and a case of systemic onset JIA with haemophagocytosis. ${ }^{216}$ Systemic onset JIA is characterised by quotidian spiking fever, macular rash, lymphadenopathy, myalgia, hepatosplenomegaly, and arthritis; also documented are polyclonal hypergammaglobulinaemia, raised liver enzymes, and raised serum and synovial fluid levels of IL1, IL6, and TNF $\alpha .{ }^{217-219}$ As with RA, B19 would seem to be associated with a minority of cases of JIA, and may be only one of a number of triggers.

\section{Vasculitis}

The term vasculitis refers to a heterogeneous group of diseases characterised by inflammation and destruction of blood vessels, and the aetiological factors for most cases remain unclear. ${ }^{189}$ Various case reports present evidence of the involvement of B19 infection in vasculitis. ${ }^{220-226}$ Peaks of incidence of giant cell arteritis (GCA) paralleled the peaks of incidence of B19 infection in Olmsted County, Minnesota, leading Gabriel and colleagues to examine 50 patients presenting for temporal artery biopsy for B19 DNA. ${ }^{227}$ They found B19 DNA in temporal artery biopsy tissue of seven of 13 patients with GCA and in only four of 37 subjects without vasculitis $(p=0.0013)$, suggesting an aetiological role for B19 in GCA. However, studies have not found evidence for B19 infection as the cause of polyarteritis nodosa $^{228}$ and Wegener's granulomatosis. ${ }^{229}$

\section{Systemic lupus erythematosus}

SLE is a multisystem inflammatory disease of unknown cause which is associated with autoantibody production. ${ }^{189}$ Many prominent features of both B19 infection and SLE overlap (fever, rash, arthralgia, cytopenias, anaemia, hepatitis, and antinuclear antibody), and acute B19 infection may mimic or exacerbate SLE. ${ }^{111}{ }^{230-238}$ B19 infection has also been associated with Kikuchi's histiocytic necrotising lymphadenitis in association with SLE. ${ }^{165}$ Antiphospholipid antibodies produced during acute B19 infection seem to have the same specificity as those produced in SLE. ${ }^{61}$ However, there was no increased seroprevalence among 
99 patients with SLE compared with 99 healthy controls matched for age and sex. ${ }^{239}$ Although the pathogenesis is not understood, it seems that B19 may precipitate or mimic SLE in a minority of cases.

\section{Systemic sclerosis}

Systemic sclerosis is a multisystem disease that affects the skin and internal organs, including the gastrointestinal tract, lung, heart, kidney, and peripheral nervous system. ${ }^{240}$ B19 DNA was detected in the bone marrow of 12 of 21 $(57 \%)$ patients with systemic sclerosis compared with 0 of 15 healthy controls $(\mathrm{p}<0.01)$; serum NS1 antibodies occurred in 33\% of patients with systemic sclerosis compared with $13 \%$ of controls. ${ }^{241}$

Uveitis

Two cases of B19 associated uveitis have been reported: one in an adult with EI, tonic pupils, and ophthalmoplegia, ${ }^{242}$ and one in a young girl associated with transient antinuclear antibody and rheumatoid factor production. ${ }^{243}$ Anti-B19 IgG was found in vitreous fluid from three of six IgG seropositive cases of chronic intermediate uveitis, but none had evidence of local antiB19 IgG production. ${ }^{244}$

\section{Myositis}

Increases in muscle enzymes are occasionally seen in acute B19 infection, ${ }^{235}$ and one child with new onset of juvenile dermatomyositis was shown to have acute B19 infection. ${ }^{24}$ A childhood case of B19 associated interstitial lung disease, hepatitis, and myositis has been reported. ${ }^{246}$ In addition, B19 DNA was isolated from the skeletal muscle of an adult patient with mixed connective tissue disease. ${ }^{247}$

\section{Conclusion}

Infection with human parvovirus $\mathrm{B} 19$ has been associated commonly with a range of clinical manifestations, such as EI, arthralgia, TAC, and fetal death and, less commonly, with miscellaneous skin conditions, haematological manifestations, hepatitis, neurological syndromes such as encephalitis and meningitis, and rheumatic diseases, including CFS, fibromyalgia, JIA, RA, SLE, systemic sclerosis, vasculitis, uveitis, and myositis. However, evidence implicating B19 virus in the causation of rheumatic disease has been conflicting and in certain cases the presence of B19 virus has even been reported to be associated with a reduced severity. ${ }^{214}{ }^{241}$ However, a significant number of reports, some of which are prospective, clearly implicate B19 virus in the pathogenesis of certain cases of rheumatic disease, such as RA, JIA, SLE, and vasculitis It is the belief of this author, however, that for each of these diseases B19 infection is only one of a number of triggers. IL6 is a recurring theme in the pathogenesis both of rheumatic disease and of B19 infection. However, the significance of the ability of NS1 to upregulate human IL6 in vivo awaits discovery. In addition, increasing evidence for B19 persistence suggests that this virus infection may prove useful as a model for the interaction of DNA viruses with humans.
1 Cossart YE, Field AM, Cant B, Widdow D. Parvovirus-like particles in human sera. Lancet 1975;i:72-3.

2 Pattison JR, Jones SE, Hodgson J, Davis LR, White JM, Stroud CE, et al. Parvovirus infections and hypoplastic crisis in sickle-cell anaemia. Lancet 1981;i:664-5.

3 Deiss V, Tratschin JD, Weitz M, Siegl G. Cloning of the human parvovirus B19 genome and structural analysis of its palindromic termini. Virology 1990;175:247-54.

4 Summers J, Jones SE, Anderson MJ. Characterisation of the genome of the agent of erythrocyte aplasia permits its classification as a human parvovirus. J Gen Virol 1983;64: 2527-32.

5 Astell CR, Luo W, Brunstein J, St Amand J. B19 parvovirus; biochemical and molecular features. In: Anderson LJ, Young NS, eds. Human parvovirus B19. Basel: Karger, 1997;20:16-41. (Monogr Virol.)

6 Christensen J, Cotmore SF, Tattersall P. Two new members of the emerging KDWK family of combinatorial transcriptional modulators bind as a heterodimer to flexibly spaced PuCGPy half-sites. Mol Cell Biol 1999;19:7741-50.

7 Blundell MC, Beard C, Astell CR. In vitro identification of a B19 parvovirus promoter. Virology 1987;157:534-8.

8 Ozawa K, Young NS. Characterisation of capsid and noncapsid proteins of B19 parvovirus propagated in human erythroid bone marrow cell cultures. J Virol 1987;61:2627-30

9 Shade RO, Blundell MC, Cotmore SF, Tattersall P, Astell CR. Nucleotide sequence and genome organisation of human parvovirus B19 isolated from the serum of a child during aplastic crisis. J Virol 1986;58:921-36.

10 Cotmore SF, Tattersall P. A genome-linked copy of the NS1 polypeptide is located on the outside of infectious parvovirus particles. J Virol 1989;63:3902-11.

11 Ozawa K, Ayub J, Kajigaya S, Shimada T, Young N. The gene encoding the nonstructural protein of B19 (human) gene encoding the nonstructural protein of B19 (human) parvovirus

12 Momoeda M, Wong S, Kawase M, Young NS, Kajigaya S. A putative nucleoside triphosphate-binding domain in the nonstructural protein of B19 parvovirus is required for cytotoxicity. J Virol 1994;68:8443-6.

13 Moffatt S, Tanaka N, Tada K, Nose M, Nakamura M, Muraoka $\mathrm{O}$, et al. A cytotoxic nonstructural protein, NS1, of human parvovirus B19 induces activation of interleukin-6 gene expression. J Virol 1996;70:8485-91.

14 Moffatt S, Yaegashi N, Tada K, Tanaka N, Sugamura K. Human parvovirus B19 nonstructural protein (NS1) induces apoptosis in erythroid lineage cells. J Viro 1998;72:3018-28.

15 Cotmore SF, McKie VC, Anderson LJ, Astell CR, Tattersall P. Identification of the major structural and nonstructural proteins encoded by human parvovirus B19 and mapping of their genes by prokaryotic expression of isolated genome of their genes by prokaryotic expressior
fragments. J Virol 1986;60:548-57.

16 Rosenfield SJ, Yoshimoto K, Kajigaya S, Anderson S, Young NS, Field A, et al. Unique region of the minor capsid protein of human parvovirus B19 is exposed on the virion surface. J Clin Invest 1992;89:2023-9.

17 Kajigaya S, Shimada T, Fujita S, Young NS. A genetically engineered cell line that produces empty capsids of B19 (human) parvovirus. Proc Natl Acad Sci USA 1989;86: 7601-5.

18 Kerr JR, Umene $\mathrm{K}$. The molecular epidemiology of parvovirus B19. Reviews in Medical Microbiology 1995;8: 21-31

19 Umene K, Nunoue T. A new genome type of human parvovirus B19 present in sera of patients with encephalopathy. J Gen Virol 1995;76:2645-51.

20 Ozawa K, Kurtzman GJ, Young N. Replication of the B19 parvovirus in human bone marrow cell cultures. Science parvovirus in human

21 Srivastava A, Lu L. Replication of B19 parvovirus in highly enriched hemopoietic progenitor cells from normal human bone marrow. J Virol 1988;62:3059-63.

22 Brown KE, Mori J, Cohen BJ, Field AM. In vitro propagation of parvovirus B19 in primary fetal liver culture. J Gen Virol 1991;72:741-5.

23 Yaegashi N, Shiraishi H, Takeshita T, Nakamura M, Yajima A, Sugamura K. Propagation of human parvovirus B19 in primary culture of erythroid lineage cells derived from fetal liver. J Virol 1989;63:2422-6.

24 Takahashi T, Ozawa K, Mitani K, Miyazono K, Asano S, Takaku F. B19 parvovirus replicates in erythroid leukaemic cells. J Infect Dis 1989;160:548-9.

25 Srivastava CH, Zhou S, Munshi NC, Srivastava A. Parvovirus B19 replication in human umbilical cord blood cells. rus B19 replication in hum

26 Sosa CE, Mahony JB, Luinstra KE, Sternbach M, Chernesky MA. Replication and cytopathology of human parvovirus B19 in human umbilical cord blood erythroid progenitor cells. J Med Virol 1992;36:125-30.

27 Serke S, Schwarz TF, Baurmann H, Kirsch A, Hottentrager $\mathrm{B}$, Von Brunn A, et al. Productive infection of in vitro generated haemopoietic progenitor cells from normal human adult peripheral blood with parvovirus B19: studies by morphology, immunocytochemistry, flow-cytometry and DNA hybridisation. Br J Haematol 1991;79:6-13.

28 Schwarz TF, Serke S, Hottenträger B, Von Brunn A, Baurmann H, Kirsch A, et al. Replication of parvovirus B19 in haematopoietic progenitor cells generated in vitro from 29 Brown KE, Anderson SM, Young NS. Erythrocyte P antigen: cellular receptor for B19 parvovirus. Science $1993 ; 262: 114-17$ 
30 Brown KE, Hibbs JR, Gallinella G, Anderson SM, Lehman $\mathrm{ED}$, McCarthy $\mathrm{P}$, et al. Resistance to parvovirus B19 infec-
tion due to lack of virus receptor (reythrocyte $\mathrm{P}$ antigen). N tion due to lack of virus receptor

31 Stults CL, Sweeley CC, Macher BA. Glycosphingolipids: structure, biological source and properties. Methods Enzymol 1989; 179:167-214.

32 Cooling LLW, Koerner TAW, Naides SJ. Multiple glycosphingolipids determine the tissue tropism of parvovirus B19. J Infect Dis 1995;172:1198-205.

33 Anderson MJ, Higging PG, Davis LR, Willman JS, Jones SE, Kidd IM, et al. Experimental parvovirus infection in humans. J Infect Dis 1985;152:257-65.

34 Saarinen UM, Chorba TL, Tattersall P, Young NS, Anderson LJ, Palmer E, et al. Human parvovirus B19-induced epidemic acute red cell aplasia in patients with hereditary hemolytic anemia. Blood 1986;67:1411-17.

35 Anderson LJ, Tsou C, Parker RA, Chorba TL, Wulff $\mathrm{H}$, Tattersall $\mathrm{P}$, et al. Detection of antibodies and antigens of human parvovirus B19 by enzyme-linked immunosorbent assay. J Clin Microbiol 1986;24:522-6.

36 Erdman DD, Usher MJ, Tsou C, Caul EO, Gary GW, Kajigaya $\mathrm{S}$, et al. Human parvovirus B19 specific IgG, IgA and IgM antibodies and DNA in serum specimens from persons with erythema infectiosum. J Med Virol 1991;35: 110-15.

37 Von Poblotzki A, Gigler A, Lang B, Wolf H, Modrow S. Antibodies to parvovirus B19 NS1 protein in infected individuals. J Gen Virol 1995;76:519-27.

38 Kerr JR, Cunniffe VS. Antibodies to parvovirus B19 nonstructural protein are associated with chronic but not acute arthritis following B19 infection. Rheumatology (in press).

39 Von Poblotzki A, Hemauer A, Gigler A, PuchhammerStockl E, Heinz FX, Pont J, et al. Antibodies to the nonstructural protein of parvovirus B19 in persistently 1995;172:1356-9.

40 Young NS, Mortimer PP, Moore JG, Humphries RK. Characterisation of a virus that causes transient aplastic crisis. J Clin Invest 1984;73:224-30.

41 Von Poblotzki A, Gerdes C, Reischl U, Wolf H, Modrow S. Lymphoproliferative responses after infection with human parvovirus B19. J Virol 1996;70:7327-30.

42 Mortimer PP, Luban NLC, Kelleher JF, Cohen BJ. Transmission of serum parvovirus like virus by clotting factor concentrates. Lancet 1983;ii:482-4.

43 Anderson MJ, Davis LR, Hodgson J, Jones SE, Murtaza L, Pattison JR, et al. Occurrence of infection with a parvovirus like agent in children with sickle cell anaemia during a two like agent in children with sickle cell anaemiod. J Clin Pathol 1982;35:744-9.

44 Potter CG, Potter AC, Hatton CSR, Chapel HM, Anderson MJ, Pattison JR, et al. Variation of erythroid and myeloid
precursors in the marrow and peripheral blood of volunteer precursors in the marrow and peripheral blood of volunteer subjects infected with

45 Schwarz TF, Wiersbitzky S, Pambor M. Case report: detection of parvovirus B19 in a skin biopsy of a patient with erythema infectiosum. J Med Virol 1994;43:171-4. 46 Anderson MJ. Human parvoviruses. In: Zuckerman AJ, clinical virology. New York: Wiley, 1990:561-72.

47 Naides SJ, Howard EJ, Swack NS, True CA, Stapleton JT. Parvovirus B19 infection in human immunodeficiency virus type 1 -infected persons failing or intolerant to zidovudine therapy. J Infect Dis 1993;168:101-5.

48 Kinney JS, Anderson LJ, Farrar J, Strikas RA, Kumar ML, Kliegman RM, et al. Risk of adverse outcomes of pregnancy after human parvovirus B19 infection. J Infect Dis 1988:157:663-7.

49 Takahashi Y, Murai C, Shibata S, Munakata Y, Ishii T, Ishii $\mathrm{K}$, et al. Human parvovirus B19 as a causative agent for rheumatoid arthritis. Proc Natl Acad Sci USA 1998;95. 8227-32.

50 Miki NP, Chantler JK. Non-permissiveness of synovial membrane cells to human parvovirus B19 in vitro. J Gen virol 1992;73:1559-62.

51 Brown KE. Human parvovirus B19 epidemiology and clinical manifestations. In: Anderson LJ, Young NS, eds. Human parvovirus B19. Basel: Karger, 1997;20:42-60. (Monogr Virol.)

52 Frickhofen N, Abkowitz JL, Safford M, Berry JM, Antunezde-Mayolo J, Astrow A, et al. Persistent B19 parvovirus infection in patients infected with human immunodeficiency virus type 1 (HIV-1): a treatable cause of anemia in ciency virus type 1 (HIV-1): a treatable cause

53 Denning DW, Amos A, Rudge P, Cohen BJ. Neuralgic amyotrophy due to parvovirus infection. J Neurol Neurosurg Psychiatry 1987;50:641-2.

54 Walsh KJ, Armstrong RD, Turner AM. Brachial plexus neuropathy associated with human parvovirus infection. BM] 1988;296:896.

55 Morey AL, Ferguson DJ, Fleming KA. Ultrastructural features of fetal erythroid precursors infected with parvovirus B19 in vitro: evidence of cell death by apoptosis. J Pathol 1993;169:213-20.

56 Sol N, Le Junter J, Vassias I, Freyssinier JM, Thomas A, Prigent AF, et al. Possible interactions between the NS-1 protein and tumour necrosis factor alpha pathways in erythroid cell apoptosis induced by human parvovirus B19. J Virol 1999;73:8762-70.

57 Reid DM, Reid TMS, Brown T, Rennie JAN, Eastmond CJ. Human parvovirus B19 infection associated with arthritis. Lancet 1985;i:422-5.
58 Cohen BJ, Buckley MM, Clewley JP, Jones VE, Puttick AH, Jacoby RK. Human parvovirus infection in an early theumatoid and inflammatory arthritis. Ann Rheum Dis $1986 ; 45: 832-8$

59 Kerr JR, Coyle PV, DeLeys RJ, Patterson CC. Follow-up study of clinical and immunological findings in patients resenting with acute parvovirus B19 infection. J Med Virol 1996;48:68-75.

60 Kerr JR, Boyd N. Autoantibodies following parvovirus B19 infection. J Infect 1996;32:41-7.

61 Loizou S, Cazabon JK, Walport MJ, Tait D, So AK. Similarities of specificity and cofactor dependence in serum antiphospholipid antibodies from patients with human parvovirus B19 infection and from those with systemic lupus erythematosus. Arthritis Rheum 1997;40: 103-8.

62 Lunardi C, Tiso M, Borgato L, Nanni L, Millo R, De Sandre $\mathrm{G}$, et al. Chronic parvovirus B19 infection induces the production of anti-virus antibodies with autoantigen binding properties. Eur J Immunol 1998;28:936-48.

63 Sekine T, Kato T, Masuko-Hongo K, Nakamura H, Yoshino $\mathrm{S}$, Nishioka $\mathrm{K}$, et al. Type II collagen is a target antigen of clonally expanded $T$ cells in the synovium of patients with rheumatoid arthritis. Ann Rheum Dis 1999;58:446-50.

64 Hall WH. Human T-cell lymphotropic virus type 1 and cutaneous $\mathrm{T}$ cell leukaemia/lymphoma. J Exp Med 1994;180:1581-5.

65 Muraoka O, Tsuneyasu K, Makoto T, Hirano T. Transcriptional activation of the interleukin-6 gene by HTLV-1 p40tax through an NF-אB-like binding site. Immunol Lett 1993;37:159-65.

66 Giuseppe S, Ruocco MR, Ambrosino C, Mallardo M, Giordano V, Baldassarre F, et al. The expression of the interleukin 6 gene is induced by the human immunodeficiency virus 1 tat protein. J Exp Med 1994;179:961-71.

67 Nishioka K, Maruyama I, Sato K, Kitajima I, Nakajima Y, Osame M. Chronic inflammatory arthropathy associated with HTLV-1. Lancet 1989;i:441.

68 Green EJ, Hinrichs SH, Vogel J, Jay G. Exocrinopathy resembling Sjögren's syndrome in HTLV-1 tax transgenic mice. Nature (London) 1989;341:72-4.

69 Iwakura Y, Tosu M, Yoshida E, Takiguchi M, Sato K, Kitajima I, et al. Induction of inflammatory arthropathy resemling rehumatoid arthritis in mice transgenic for HTLV-1. Science 1991;253:1026-8.

70 Nakajima T, Aono H, Hasunuma T, Yamamoto K, Maruyama I, Nosaka T, et al. Overgrowth of human synovial cells driven by the human $\mathrm{T}$ cell leukaemia virus type 1 tax gene. J Clin Invest 1993;92:186-93.

71 Wagner AD, Goronzy JJ, Matteson EL, Weyand CM. Systemic monocyte and $\mathrm{T}$ cell activation in a patient with human parvovirus B19 infection. Mayo Clin Proc 1995;70: 261-5.

72 Watanabe $M$, Shimamoto Y, Yamaguchi M, Inada S, Miyazaki S, Sato H. Viral-associated haemophagocytosis and elevated serum TNF- $\alpha$ with parvovirus B19-related pancytopenia in patients with hereditary spherocytosis. Clin Lab Haematol 1994;16:179-82.

73 Aasted B, Tierney GS, Bloom ME. Analysis of the quantity of antiviral antibodies from mink infected with different Aleutian disease virus strains. Scand J Immunol 1984;19: 395-402

74 Bloom ME, Alexandersen S, Mori S, Wolfinbarger JB. Analysis of parvovirus infections using strand-specific hybridistation probes. Virus Res 1989;14:1-26.

75 Porter DD, Larsen AE, Proter HG. The pathogenesis of Aleutian disease of mink. I. In vivo viral replication and the
host antibody response to viral antigen. J Exp Med 1969;130:575-89.

76 Porter DD, Larsen AE, Porter HG. The pathogenesis of Aleutian disease of mink. III. Immune complex arteritis. Am J Pathol 1973;71:331-44.

77 Mori S, Wolfinbarger JB, Miyazawa M, Bloom M. Replication of Aleutian mink disease parvovirus in lymphoid tissues of adult mink: involvement of follicular dendritic cells and macrophages. J Virol 1991;65:952-6.

78 Alexandersen S, Bloom ME, Wolfinbarger J. Evidence of restricted viral replication in adult mink infected with Aleutain disease of mink parvovirus. J Virol 1988;62:1495507.

79 Karetnyi YV, Beck PR, Markin RS, Langnas AN, Naides SJ. Human parvovirus B19 infection in acute fulminant liver failure. Arch Virol 1999;144:1713-24.

80 Saal JG, Stendle M, Einsele H, Muller CA, Fritz P, Zacher J. Persistence of B19 parvovirus in synovial membranes of patients with rheumatoid arthritis. Rheumatology 1992;12: $147-51$

81 Kerr JR, Kane D, Crowley B, Leonard N, O’Briain S, Coyle PV, et al. Parvovirus B19 infection in AIDS patients. Int J STD AIDS 1997;8:184-6.

82 Kerr JR, Cartron JP, Curran MD, Moore JE, Elliott JRM, Mollan RAB. A study of the role of parvovirus B19 in rheumatoid arthritis. Br J Rheumatol 1995;34:809-13.

83 Soderlund M, von Essen R, Haapasaari J, Kilstala U, Kiviluoto O, Hedman K. Persistence of parvovirus B19 DNA in synovial membranes of young patients with and without chronic arthropathy. Lancet 1997;349:1063-5.

84 Diss TC, Pan LX, Du MQ, Peng HZ, Kerr JR. Parvovirus B19 is associated with benign testes as well as testicular germ cell tumours. Mol Pathol 1999;52:349-52.

85 Nikkari S, Vuorinen T, Kotilainen P, Lammintausta K. Presence of parvovirus B19 DNA in the skin of healthy individuals [abstract]. Arthritis Rheum 1999;42:S338. 
86 Kerr JR, Curran MD, Moore JE, Murphy PG. Parvovirus B19 infection; persistence and genetic variation. Scand J

87 Kotin RM, Siniscalco M, Samulski RJ, Zhu XD, Hunter L, Laughlin CA, et al. Site-specific integration by adenoasso

88 Speyer I, Breedveld FC, Dijkmans BAC. Human parvovirus B19 infection is not followed by inflammatory joint disease during long-term follow-up. Clin Exp Rheumatol 1998;16: 576-8.

89 Kelleher JF Jr, Luban NL, Cohen BJ, Mortimer PP. Human serum parvovirus as the cause of aplastic crisis in sickle cell disease. Am J Dis Child 1984;138:401-3.

90 Lefrere JJ, Courouce AM, Girot R, Cornu P. Human parvovirus and thalassaemia. J Infect 1986;13:45-9.

91 Lefrere JJ, Girot R, Courouce AM, Maier-Redelsperger M, Cornu P. Familial human parvovirus infection associated with anemia in siblings with heterozygous betawith anemia in siblings with heter

92 Bertrand Y, Lefrere JJ, Leverger G, Courouce AM, Feo C, Clark $M$, et al. Autoimmune haemolytic anaemia revealed by human parvovirus-linked erythroblastopenia. Lancet 1985;ii:382-3.

93 Goldman F, Rotbart H, Gutierrez K, Ambruso D Parvovirus-associated aplastic crisis in a patient with red blood cell glucose-6-phosphate dehydrogenase deficiency. Pediatr Infect Dis J 1990;9:593-4.

94 Lefrere JJ, Courouce AM, Girot R, Bertrand Y, Soulier JP. Six cases of hereditary spherocytosis revelaed by human parvovirus infection. Br J Haematol 1986;62:653-8.

95 Tsukada T, Koike T, Koike R, Sanada M, Takahashi M, Shibata A, et al. Epidemic of aplastic crisis in patients with hereditary spherocytosis in Japan. Lancet 1985;i:1401.

96 Mabin DC, Chowdhury V. Aplastic crisis caused by human parvovirus in two patients with hereditary stomatocytosis. parvovirus in two patients with

97 Lefrere JJ, Bourgeois H. Human parvovirus associated with erythroblastopenia in iron deficiency anaemia. J Clin Pathol 1986;39:1277-8.

98 Duncan JR, Potter CB, Cappellini MD, Kurtz JB, Anderson MJ, Weatherall DJ. Aplastic crisis due to parvovirus infection in pyruvate kinase deficiency. Lancet 1983;ii:14-16.

99 Mehta J, Singhal S, Mehta BC. Aplastic crisis and leg ulceration: two rare complications of hereditary sideroblastic anaemia. J Assoc Physicians India 1992;40:466-7.

100 West NC, Meigh RE, Mackie M, Anderson MJ. Parvovirus infection associated with aplastic crisis in a patient with HEMPAS. J Clin Pathol 1986;39:1019-20.

101 Rechavi G, Vonsover A, Manor Y, Mileguir F, Shpilberg O, Kende $G$, et al. Aplastic crisis due to human parvovirus B19 infection in red cell pyrimidine-5'-nucleotidase deficiency. Acta Haematol 1989;82:46-9.

102 Brass C, Elliott LM, Stevens DA. Academy rash, a probable epidemic of erythema infectiosum (fifth disease) JAMA 1982;248:568-72.

103 Ager A, Chin TDY, Poland JD. Epidemic erythema infectiosum. N Engl J Med 1966;275:1326-31.

104 Balfour HH. Erythema infectiosum (fifth disease): clinical review and description of 91 cases seen in an epidemic. Clin Pediatr (Phila) 1969;8:721-7.

105 Woolf AD, Campion GV, Chiswick A, Wise S, Cohen BJ, Klouda PT, et al. Clinical manifestations of human parvovirus B19 in adults. Arch Intern Med 1989;149:1153-6.

106 Anderson MJ, Lewis E, Kidd IM, Hall SM, Cohen BJ. An outbreak of erythema infectiosum associated with human parvovirus infection. Journal of Hygiene, Cambridge 1984; parvovirus

107 Joseph PR. Fifth disease: the frequency of joint involvement in adults. New York State Journal of Medicine 1986 ment in ad $86: 560-3$.

108 White DG, Woolf AD, Mortimer PP, Cohen BJ, Blake DR, Bacon PA. Human parvovirus arthropathy. Lancet 1985; i: 419-21.

09 Naides SJ, Scharosch LL, Foto F, Howard EJ. Rheumatologic manifestations of human parvovirus B19 infection in adults. Initial two-year clinical experience. Arthritis Rheum 1990;33:1297-309.

110 Nikkari S, Lukkainen R, Mottonen T, Meurman O, Hannonen P, Skurnik M, et al. Does parvovirus B19 have a role in rheumatoid arthritis? Ann Rheum Dis 1994;53: 106-11.

111 Gran JT, Johnsen V, Myklebust G, Nordbo SA. The variable clinical picture of arthritis induced by human parvovirus B19. Report of seven adult cases and review of the vovirus B19. Report of seven adult cases and revi

112 Taylor HG, Borg AA, Dawes PT. Human parvovirus B19 and rheumatoid arthritis. Clin Rheumatol 1992;11:548-50

113 Tyndall A, Jelk W, Hirsch HH. Parvovirus B19 and erosive polyarthritis. Lancet 1994;343:480-1.

114 Dijkmans BA, van Elsacker-Niele AM, Salimans MMM, van Albada-Kuipers GA, de Vries E, Weiland HT. Human parvovirus B19 DNA in synovial fluid. Arthritis Rheum 1988;31:279-81.

115 Kandolf R, Kirschner P, Hofschneider PH, Vischer TL. Detection of parvovirus in a patient with 'reactive arthritis' by in situ hybridisation. Clin Rheumatol 1989;8:398-401.

116 Klouda PT, Corbin SA, Bradley BA, Cohen BJ, Woolf AD. HLA and acute arthritis following human parvovirus infection. Tissue Antigens 1986;28:318-19.

117 Gendi NST, Gibson K, Wordsworth BP. Effect of HLA type and hypocomplementaemia on the expression of parvovirus arthritis: one year follow up of an outbreak. Ann Rheum Dis 1996;55:63-5.
118 Jawad ASM. Persistent arthritis after human parvovirus B19 infection. Lancet 1993;341:494.

119 Dijkmans BAC, Breedveld FC, de Vries RR. HLA antigens in human parvovirus arthropathy. J Rheumatol 1986;13: $1192-3$

120 Brown T, Anand A, Ritchie LD, Clewley JP, Reid TM. ntrauterine parvovirus infection associated with hydrops fetalis. Lancet 1984;ii:1033-4.

121 Gray ES, Davidson RJ, Anand A. Human parvovirus and fetal anaemia. Lancet $1987 ; \mathrm{i}: 1144$.

122 Naides SJ, Weiner CP. Antenatal diagnosis and palliative treatment of non-immune hydrops fetalis secondary to fetal parvovirus B19 infection. Prenat Diagn 1989;9:105-14.

123 Morey AL, Keeling JW, Porter HJ, Fleming KA. Clinical and histopathological features of parvovirus B19 infection (

124 Public Health Laboratory Service Working Party on Fifth Disease. Prospective study of human parvovirus B19 infection in pregnancy. BMJ 1990;300:1166-70.

125 Gratacos E, Torres PJ, Vidal J, Antolin E, Costa J, Jimenez de Anta MT, et al. The incidence of human parvovirus B19 infection during pregnancy and its impact on perinatal outcome. J Infect Dis 1995;171:1360-3.

126 Weiland HT, Vermey-Keers C, Salimans MMM, Fleuren GJ, Verwey RA, Anderson MJ. Parvovirus B19 associated with fetal abnormality. Lancet 1987;i:682-3.

127 Tiessen RG, van Elsacker-Niele AM, Vermeij-Keers C, Opekes D, Van Roosmalen J, Gorsira MC. A fetus with parvovirus B19 infection and congenital anomalies. Prenat Diagn 1994;14:173-6.

128 Brown KE, Green SW, Antunez de Mayolo J, Bellanti JA, Smith SD, Smith TJ, et al. Congenital anaemia after transplacental B19 parvovirus infection. Lancet 1994;343: $895-6$.

129 Rao SP, Miller ST, Cohen BJ. Severe anemia due to B19 parvovirus infection in children with acute leukemia in remission. American Journal of Pediatrics, Hematology and Oncology 1990;12:194-7.

130 Kurtzman GJ, Cohen B, Meyers P, Amunullah A, Young NS. Persistent B19 parvovirus infection as a cause of severe chronic anaemia in children with acute lymphocytic leukaemia. Lancet 1988;ii:1159-62.

131 Gilsanz F, Barcia Vela J, Vargas JA, Ibanez J, Ona F, Lopez $\mathrm{J}$, et al. Acquired pure red cell aplasia: a study of six cases. Ann Hematol 1995;71:181-3.

32 Graeve JL, de Alarcon PA, Naides SJ. Parvovirus B19 infection in patients receiving cancer chemotherapy: the expanding spectrum of disease. American Journal of Pediatrics, Hematology and Oncology 1989;11:441-4.

133 Niitsu H, Takatsu H, Miura I, Chubachi A, Ito T, Hirokawa $\mathrm{M}$, et al. Pure red cell aplasia induced by B19 parvovirus during allogeneic bone marrow transplantation. Rinsho Ketsueki 1990;31:1566-71.

134 Amiot L, Langanay T, Drenou B, Lelong B, Le Prise PY, Logeais $\mathrm{Y}$, et al. Spontaneous recovery from severe parvovirus B19 pure red cell aplasia in a heart transplant recipient as demonstrated by marrow culture. Hematology and Cell Therapy 1998;40:71-3.

135 Ndimbie OK, Frezza E, Jordan JA, Koch W, Van Theil DH. Parvovirus B19 in anemic liver transplant recipients. Clin Diagn Lab Immunol 1996;3:756-60.

136 Koch WC, Massey G, Russell CE, Adler SP. Manifestations and treatment of human parvovirus B19 infection in immunocompromised patients. J Pediatr 1990;116:355-9.

137 Kurtzman GJ, Ozawa K, Cohen B, Hanson G, Oseas R, Young NS. Chronic bone marrow failure due to persistent Boung NS. Chronic bone marrow failure due to persistent

B19 parvovirus infection. N Engl J Med 1987;317:287-94.
138 Davidson JE, Gibson B, Gibson A, Evans TJ. Parvovirus infection, leukaemia and immunodeficiency. Lancet 1989; i: 102 .

139 Gahr M, Pekrun A, Eiffert H. Persistence of parvovirus B19 DNA in blood of a child with severe combined immunodeficiency associated with chronic pure red cell aplasia. Eur J Pediatr 1991;150:470-2.

40 Kurtzman GJ, Cohen BJ, Field AM, Oseas R, Blaese RM, Young NS. Immune response to B19 parvovirus and an antibody defect in persistent viral infection. J Clin Invest $1989 ; 84: 1114-23$

141 Lefrere JJ, Courouce AM, Bigorie B, Truchaud F, Muller JY, Soulier JP. Vascular purpura caused by human parvoviruses. Presse Med 1985;14:2065.

142 Mortimer PP, Cohen BJ, Rossiter MA. Human parvovirus and purpura. Lancet 1985;i:730-1.

143 Shiraishi H, Umetsu K, Yamamoto H, Hatakeyama Y, Yaegashi N, Sugamura K. Human parvovirus (HPV/B19) infection with purpura. Microbiol Immunol 1989;33:36972 .

144 Lefrere JJ, Courouce AM, Soulier JP, Cordier MP, Guesne Girault MC, Polonovski C, et al. Henoch-Schönlein purpura and human parvovirus infection. Pediatrics 1986; 78:183-4

145 Bagot M, Revuz J. Papular-purpuric 'gloves and socks' syndrome: primary infection with parvovirus B19? J Am Acad Dermatol 1991;25:341-2.

146 Halasz CLG, Cormier D, Den M. Petechial glove and sock syndrome caused by parvovirus B19. J Am Acad Dermatol 1992;27:835-8.

147 Borreda D, Palomera S, Gilbert B, Lienhardt A, de Lumley L. A propos de vingt-quatre observations d'evolution etale. Pediatrie 1991;46:597-9.

148 Lacaze T, de Prost Y, Lefrere JJ, Courouce AM. Parvovirus $\mathrm{B} 19$ et cinquieme maladie. Archives Français Pediatrie 1987;44:619-20. 
149 Dinerman JL, Corman LC. Human parvovirus B19 arthropathy associated with desquamation. Am J Med

150 Naides SJ, Piette W, Veach LA, Argenyi Z. Human parvovirus B19-induced vesiculopustular skin eruption. Am J Med 1988;84:968-72.

151 Lobkowicz F, Ring J, Schwarz TF, Roggendorf $M$ Erythema multiforme in a patient with acute human parvovirus B19 infection. J Am Acad Dermatol 1989;20: 849-50.

152 Garcia-Tapia AM, Martinez-Rodriguez A, FernandezGutierrez C, Mira J, Lechuga JL. Eritema multiforme ampolloso por parvovirus humano B19. Enferm Infecc Microbiol Clin 1993;11:575-6.

153 Dereure O, Montes B, Guilhou JJ, Acute generalised livedo reticularis with myasthenia-like syndrome revealing parvovirus B19 primary infection. Arch Dermatol 1995;131: virus 744 .

154 Imbert B, Brion JP, Janbon B, Gonzales M, Micoud M Erythema nouveau associe a une infection par le parvovirus B19. Presse Med 1989;18:1753-4.

155 Osaki M, Matsubara K, Iwasaki T, Kurata T, Nigami $H$, Harigaya $\mathrm{H}$, et al. Severe aplastic anemia associated with human parvovirus B19 infection in a patient without underlying disease. Ann Hematol 1999;78:83-6.

156 Bertoni E, Rosati A, Zanazzi M, Azzi A, Zakrzewska K, Guidi S, et al. Unusual incidence of aplastic anaemia due to B19 parvovirus infection in renal transplant recipients. Transplant Proc 1997;29:818-19.

157 Gautier E, Bourhis JH, Bayle C, Cartron J, Pico JL, Tchernia G. Parvovirus B19 associated neutropenia. Treatment with Rh G-CSF. Hematology and Cell Therapy 1997;39: $85-7$.

158 Pont J, Puchhammer-Stock1 E, Chott A, Popow-Kraupp T, Kienzer H, Postner G, et al. Recurrent granulocytic aplasia Kienzer $H$, Postner $G$, et al. Recurrent granulocytic aplasia as clinical presentation of a persistent

159 Muir K, Todd WTA, Watson WH, Fitzsimmons E. Viral-associated haemophagocytosis with parvovirus B19related pancytopenia. Lancet 1992;339:1139-40.

160 Shirono K, Tsuda H. Parvovirus B19-associated haemophagocytic syndrome in healthy adults. $\mathrm{Br} \mathrm{J}$ Haemato 1995;89:923-6.

61 Currie JM, Adamson DJA, Brown T, Dawson AA. The fifth cause of splenomegaly? Parvovirus B19. Clin Lab Haematol 1992;14:327-30.

162 van Elsacker-Niele AM, Weiland HT, Kroes AC, KappersKlunne MC. Parvovirus B19 infection and idiopathic thrombocytopenic purpura. Ann Hematol 1996;72:141-4.

163 Plummer FA, Hammond GW, Forward K, Sekla L, Thompson LM, Jones SE, et al. An erythema infectiosumlike illness caused by human parvovirus infection. N Engl J Med 1985;313:74-9.

164 Nagai K, Morohoshi T, Kudoh T, Yoto Y, Suzuki N, Matsunaga Y. Transient erythroblastopenia of childhood with megakaryocytopenia associated with human
B19 infection. Br J Haematol 1992;80:131-2.

165 Meyer O, Kahn MF, Grossin M, Ribard P, Belmatoug N, Morinet F, et al. Parvovirus B19 infection can induce histiocytic necrotising lymphadenitis (Kikuchi's disease) associated with systemic lupus erythematosus. Lupus 1991;1:37-41.

166 Naides SJ, Transient liver enzyme abnormalities in acute human parvovirus (HPV) infection. Clinical Resc 1987;35:859.

167 Tsuda H. Liver dysfunction caused by parvovirus B19. Am J Gastroenterol 1993;88:1463.

168 Langnas AN, Markin RS, Cattral MS, Naides SJ. Parvovirus B19 as a possible causative agent of fulminant liver failure and associated aplastic anaemia. Hepatol 1995;22: $1661-5$.

169 Yoto Y, Kudoh T, Asanuma H, Numasaki K, Tsutsumi Y, Nakata S, et al. Transient disturbance of consciousness and hepatic dysfunction associated with human parvovirus B19 infection. Lancet 1994;344:624-5.

170 Sokal EM, Melchoir M, Cornu C, Vandenbroucke AT, Buts JP, Cohen BJ, et al. Acute parvovirus B19 infection associated with fulminant hepatitis of favourable prognosis in young children. Lancet 1998;352:1739-41.

171 Balfour HH Jr, Schiff GM, Bloom JE. Encaphalitis associated with erythema infectiosum. JAMA 1970;77:133-6.

172 Hall CB, Horner FA. Encephalopathy with erythema infectiosum. Am J Dis Child 1977;131:65-7.

173 Watanabe T, Satoh M, Oda Y. Human parvovirus B19 encephalopathy. Arch Dis Child 1994;70:71

174 Okumura A, Ichikawa T. Aseptic meningitis caused by human parvovirus B19. Arch Dis Child 1993;68:784 5 .

175 Cassinotti P, Schultze D, Schlageter P, Chevili S, Siegl G. Persistent human parvovirus B19 infection following an acute infection with meningitis in an immunocompeten patient. Eur J Clin Microbiol Infect Dis 1993;12:701-4.

76 Chundu KR, Lal S, Bartley DL. Multiple organ dysfunction caused by parvovirus B19. West J Med 1995;163: $574-6$.

177 Balkaran B, Char G, Morris JS, Thomas PW, Serjeant BE, Serjeant GR. Stroke in a cohort of patients with homozygous sickle cell disease. J Pediatr 1992;120:360-6.

178 Nagahama Y, Shimohama S, Kaji R, Akiguchi I, Kimura J. An adult case of transverse myelitis with erythema
infectiousum. Rinsho Shinkeigaku 1992;32:1035-7.

179 Minohara Y, Koitabashi Y, Kato T, Nakajima N Murakami H, Masaki $\mathrm{H}$, et al. A case of Guillain-Barré syndrome associated with human parvovirus B19 infection. Jyndrome associated with $1998 ; 36: 327-8$.
180 Shimizu Y, Ueno T, Komatsu H, Takada H, Nunoue T. Acute cerebellar ataxia with human parvovirus B19 infection. Arch Dis Child 1999;80:72-3.

181 Samii K, Cassinotti P, de Freudenreich J, Gallopin Y, Le Fort D, Stalder H. Acute bilateral carpal tunnel syndrome associated with human parvovirus B19 infection. Clin Infect Dis $1996 ; 22: 162-4$

182 Faden H, Gary GW Jr, Korman M. Numbness and ingling of fingers associated with parvovirus B19 infection. $\mathrm{J}$ Infect Dis 1990;161:354-5.

183 Jacks TA. Pruritis in parvovirus infection. J R Coll Gen Pract 1987;37:210-11.

184 Fukuda K, Straus SE, Hickie I, Sharpe MC, Dobbins JG, Komaroff A. The chronic fatigue syndrome. A comprehensive approach to its definition and study. Ann Intern Med 1994;121:953-9.

185 Chao CC, Janoff EN, Hu SX, Thomas K, Gallagher M, Tsang $M$, et al. Altered cytokine release in peripheral blood The chronic fatigue syndrome (CFS). Cytokine 1991;3:292-8.

186 Komaroff AL, Buchwald DS. Chronic fatigue syndrome; n update. Annu Rev Med 1998;49:1-13.

87 Jacobson SK, Daly JS, Thorne GM, McIntosh K. Chronic parvovirus B19 infection resulting in chronic fatigue syndrome. Clin Infect Dis 1997;24:1048-51.

188 Ilaria RL Jr, Komaroff AL, Fagioli LR, Moloney WC, True CA, Naides SJ. Absence of parvovirus B19 infection in chronic fatigue syndrome. Arthritis Rheum 1995;38: 2473-5

189 Klippel JH, Dieppe PA. Rheumatology. London: Mosby, 1994. (Mosby-Year Book Europe.)

190 Leventhal LJ, Naides SJ, Freundlich B. Fibromyalgia and parvovirus infection. Arthritis Rheum 1991;34:1319-24.

191 Berg AM, Naides SJ, Simms RW. Established fibromyalgia syndrome and parvovirus B19 infection. J Rheumatol 0:1941-3.

192 Harrison B, Silman AJ, Barrett E, Symmons D. Low frequency of recent parvovirus infection in a populationbased cohort of patients with early inflammatory polyarthritis. Ann Rheum Dis 1998;57:375-7.

193 Murai C, Munakata Y, Takahashi Y, Ishii T, Shibata S, Muryoi T, et al. Ann Rheum Dis 1999;58:130-2

194 Mimori A, Misaki Y, Hachiya T, Ito K, Kano S. Prevalence of antihuman parvovirus B19 IgG antibodies in patients with refractory rheumatoid arthritis and polyarticular juvenile rheumatoid arthritis. Rheumatol Int 1994;14:87-90.

195 Lefrere JJ, Meyer O, Menkes CJ, Beaulieu CJ, Courouce AM. Human parvovirus and rheumatoid arthritis. Lancet $1985 ; 1: 982$.

196 Hajeer AH, MacGregor AJ, Rigby AS, Ollier WER, Carthy D, Silman AJ. Influence of previous exposure to human parvovirus B19 infection in explaining susceptibility to parvovirus Beumatoid arthritis: an analysis of disease in discordant twin pairs. Ann Rheum Dis 1994;53:137-9.

197 Kerr JR, Ferguson WP, McMillan SA, Bruce IN, Bell AL. Parvovirus B19 and acute joint swelling in rheumatoid arthritis patients. Ann Rheum Dis 1996;55:648-50.

198 Simpson RW, McGinty L, Simon L, Smith CA, Godzeski CW, Boyd RJ. Association of parvoviruses with rheumatoid arthritis of humans. Science 1984;223:1425.

199 Simpson RW, Van Leeuwen D, Zazra JJ. Biological and molecular properties of the RA-1 parvoviruses [abstract]. Parvovirus Workshop. Bern, Switzerland, 1985.

200 Ray NB, Nieva CDR, Seftor EA, Hendrix MJC, Naides SJ. Cartilage matrix invasion studies with primary human synovial cells and human parvovirus B19 [abstract]. Arthritis Rheum 1999;42:S339.

201 Short CL. The antiquity of rheumatoid arthritis. Arthritis Rheum 1974;17:193-205.

202 Rothschild BM, Turner KR, DeLuca MA. Symmetrical erosive peripheral polyarthritis in the Late Archaic Period of Alabama. Science 1988;241:1498-501.

203 Rothschild BM, Woods RJ, Rothschild C, Sebes JI. Geographic distribution of rheumatoid arthritis in ancient North America: implications for pathogenesis. Semin Arthritis Rheum 1992;22:181-7.

204 Altschuler EL. Parvovirus B19 and the pathogenesis of heumatoid arthritis: a case for historical reasoning. Lancet 1999;354:1026-7.

205 Chorba T, Anderson LJ. Erythema infectiosum (fifth disease). Clin Dermatol 1989;7:65-74

206 Willan R. Reports of the diseases in London. Particularly during the years 1796, '97, '98, '99 and 1800. London: HL Galabin, 1801

207 Miyazawa K, Mori A, Okudaira H. IL-6 synthesis by rheumatoid synoviocytes is autonomously upregulated at the ranscriptional level. J Allergy Clin Immunol 1999;103: S437-44.

208 Schwarz TF, Roggendorf M, Suschke H, Deinhardt F. Human parvovirus B19 infection and juvenile chronic polarthritis. Infection 1987;15:264-5.

209 Nocton JJ, Miller LC, Tucker LB, Schaller JG. Human parvovirus B19-associated arthritis in children. J Pediatr 1992;122:186-90

210 Blidi M, Gatfosse M, Barjonet G. Adult-onset Still's disease associated with acute parvovirus B19 infection in pregnancy. Ann Med Interne (Paris) 1996;147:518-19.

211 Borreda D, Palomera S, Gilbert B, Lienhardt A, de Luminfection in children. Annals Pediatrie (Paris) 1992;39: 543-9.

212 Pouchot J, Ouakil H, Debin ML, Vinceneux P. Adult Still's disease associated with acute human parvovirus B19 infection. Lancet 1993;341:1280-1. 
213 Kishore J, Misra R, Gupta D, Ayyagari A. Raised IgM antibodies to parvovirus B19 in juvenile rheumatoid arthritis. bodies to parvovirus B19 in juvenile
Indian J Med Res 1998;107:15-18.

214 Bateman HE, Kirou KA, Paget SA, Crow MK, Yee AM. Remission of juvenile rheumatoid arthritis after infection with parvovirus B19. J Rheumatol 1999;26:2482-4.

215 Longo G, Luppi M, Bertesi M, Farrera L, Torelli G, Emilia G. Still's disease, severe thrombocytopenia, and acute hepatitis associated with acute parvovirus B19 infection. Clin Infect Dis 1998;26:994-5.

216 Wada Y, Kobayashi M, Kubo M. A girl with systemic-onset juvenile rheumatoid arthritis suspected to due to human parvovirus B19 infection [Japanese]. Kansenshogaku Zasshi 1997;71:468-73.

217 De Benedetti F, Massa M, Robbioni P, Ravelli A, Burgio GR, Martini A. Correlation of serum interleukin-6 with joint involvement and thrombocytosis in systemic juvenile rheumatoid arthritis. Arthritis Rheum 1991;34:1158-63.

218 Lepore L, Pennesi M, Saletta S, Perticarari S, Presani G, Prodan M. Study of IL-2, IL-6, TNF alpha, IFN gamma and beta in the serum and synovial fluid of patients with and beta in the serum and synovial fluid of patients with juvenile

219 Mangge H, Kenzian H, Gallisti S, Neuwirth G, Liebmann $\mathrm{P}$, Laulfersch F, et al. Serum cytokines in juvenile rheumatoid arthritis. Correlation with conventional inflammation parameters and clinical subtypes. Arthritis Rheum 1995; 38:211-20

220 Andres E, Grunenberger F, Schlienger JL, Imler M. Cutaneous vasculitis disclosing parvovirus B19 infection. Ann Med Interne (Paris) 1997;148:107-8.

221 Corman LC, Dolson DJ. Polyarteritis nodosa and parvovirus B19 infection. Lancet 1992;339:491.

222 Corman LC, Staud R. Association of Wegener's granulomatosis with parvovirus B19 infection: comment on the concise communication by Nikkari et al. Arthritis Rheum 1995;38:1174-5.

223 Finkel TH, Torok TJ, Ferguson PJ, Durigon EL, Zaki SR, Leung DY, et al. Chronic parvovirus B19 infection and sysLeung DY, et al. Chronic parvovirus B19 infection and systemic necrotising vasculitis: opportunistic

224 Nikkari S, Roivainen A, Hannonen P, Mottonen T, Luukkainen R, Yli-Jama T, et al. Persistence of parvovirus B19 in synovial fluid and bone marrow. Ann Rheum Dis 1995;54:597-600.

225 Chakravarty K, Merry P. Systemic vasculitis and atypical infections: report of two cases. Postgrad Med J 1999;75: 544-6.

226 Martinelli C, Azzi A, Buffini G, Comin CE, Leoncini F Cutaneous vasculitis due to human parvovirus B19 in an HIV-infected patient: report of a case. AIDS 1997;11: 1891-3.

227 Gabriel SE, Espy M, Erdman DD, Bjornsson J, Smith TF, Hunder GG. The role of parvovirus B19 in the pathogenesis of giant cell arteritis: a preliminary evaluation. Arthritis Rheum 1999;42:1255-8.

228 Leruez-Ville M, Lauge A, Morinet F, Guillevin L, Deny P. Polyarteritis nodosa and parvovirus B19. Lancet 1994;344 Polyart.

229 Nikkari S, Vainionpaa R, Toivanen P. Association of Wegener's granulomatosis with parvovirus B19 infection. Comment on the concise communication by Nikkari et al. Arthritis Rheum 1995;38:1175.
230 Cope AP, Jones A, Brozovic M, Shafi MS, Maini RN. Possible induction of systemic lupus erythematosus by human parvovirus. Ann Rheum Dis 1992;51:803-4.

231 Glickstein SL. Lupus-like presentation of human parvovirus B19 infection. J Rheumatol 1992;19:1253.

232 Chassagne P, Mejjad O, Gourmelan O, Moore N, Le Loet $\mathrm{X}$, Deshayes P. Exacerbation of systemic lupus erythematosus during human parvovirus B19 infection. Br J Rheumatol 1993;32:158-9.

233 Vigeant P, Menard HA, Borie G. Chronic modulation of the autoimmune response following parvovirus B19 infection. J Rheumatol 1994;21:1165-7.

234 Nesher G, Osborn TG, Moore TL. Parvovirus infection mimicking systemic lupus erythematosus. Semin Arthritis Rheum 1995;24:297-303.

235 Kalish RA, Knopf AN, Gary GW, Canoso JJ. Lupus-like presentation of human parvovirus B19 infection. J Rheumatol 1992;19:169-71.

236 Hemauer A, Bechenlehner K, Wolf H, Lang B, Modrow S. Acute parvovirus B19 infection in connection with a flare of sysemic lupus erythematosus in a female patient. J Clin Virol 1999;14:73-7.

237 Tanaka A, Sugawara A, Sawai K, Kuwahara T. Human parvovirus B19 infection resembling systemic lupus erythematosus. Intern Med 1998;37:708-10

238 Trapani S, Ermini M, Falcini F. Human parvovirus B19 infection: its relationship with systemic lupus erythematosus. Semin Arthritis Rheum 1999;28:319-25.

239 Bengtsson A, Widell A, Elmstahl S, Sturfelt G. No serological indications that systemic lupus erythematosus is linked withexposure to human parvovirus B19. Ann Rheum Dis 2000;59:64-6.

240 Generini S, Fiori G, Pignone AM, Cerinic MM, Cagnoni M. Systemic sclerosis - a clinical overview. Adv Exp Med Biol 1999;455:73-83.

241 Ferri C, Zakrzewska K, Longombardo G, Giuggioli D, Storino FAA, Pasero G, et al. Parvovirus B19 infection of bone marrow in systemic sclerosis patients. Clin Exp Rheumatol 1999;17:718-20.

242 Corridan PGJ, Laws DE, Morrell AJ, Murray PI. Tonic pupils and human parvovirus B19 infection. J Clin Neurophthalmol 1991;11:109-10.

243 Maini RN, Edelstein C. Uveitis associated with parvovirus infection. Br J Ophthalmol 1999;83:1403-4.

244 De Boer JH, de Keizer RJW, Kijlstra A. In search of intraocular antibody production of parvovirus B19 and adenovirus in intermediate uveitis. Br J Ophthalmol 1993; $77: 829$.

245 Lewkonia RM, Horne D, Dawood MR. Juvenile dermatomyositis in a child infected with human parvovirus B19. Clin Infect Dis 1995;21:430-2.

246 Bousvaros A, Sundel R, Thorne GM, McIntosh K, Cohen M, Erdman DD, et al. Parvovirus B19-associated interstitial lung disease, hepatitis and myositis. Pediatr Pulmonol 1998;26:365-9.

247 Kerr JR, Barrett AM, Curran MD, Behan WMH, Middleton D, Behan PO. Parvovirus B19 and chronic fatigue syndrome. Journal of the Chronic Fatigue Syndrome 1997;3: $101-7$. 